\title{
透析患者に対する外科手術の問題点と対策 一緊急手術および消化器癌手術を中心に一
}

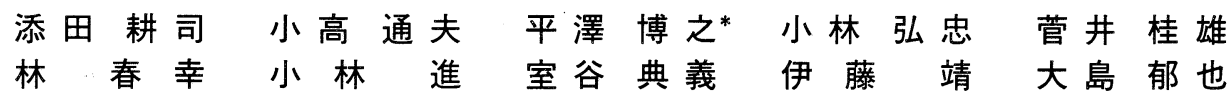
磯野可一嶋田 俊恒** 桜井信也** 織田 成 人** $^{* *}$ 千葉大学第 2 外科 同救急部・集中治療部* 千葉社会保険病院透析部**

(昭和 60 年 9 月 30 日受付)

key words : 慢性透析患者, perioperative management, 自己防御機構, biological response modifier, 消化器癌

〈要旨〉

千葉大学第 2 外科および千葉社会保険病院にて, 1966 年 12 月から 1985 年 6 月までに慢性透析患者の併存病変に対 する外科手術例を 137 例経験した。

予定手術 74 例に直死例はないが, 緊急手術 63 例中 16 例が直死例であり, 直死率は, 緊急手術群において有意に高 かった，緊急手術群では術前管理が不十分であり，重症感染症を有する症例が多かった。感染に対する自己防御機構 の検討では, 慢性透析患者は消化器手術患者に比し, 細胞性免疫能の低下, 細網内皮系貪食能の低下および補体系の 低下を認めた。透析患者は immunocompromised host であり, 手術に際し自己防御機構の賦活を念頭に置く必要が ある。

緊急手術対策として, 術前に EVAL 膜を用いた少へパリン重曹透析が必要であり，同時に輸血を行い,ヘマトクリッ

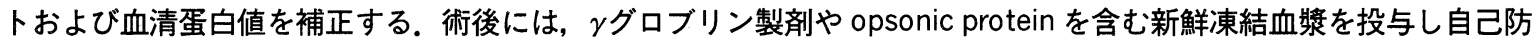
御機構の賦活に努める.

予定手術に対しては, 血液浄化法, glucose insulin 療法を組み合わせた perioperative management および術前の, biological response modifier である OK-432 投与による免疫賦活療法を施行し, 術後合併症とりわけ感染症の予防 に努める。

一方, 透析患者の増加と高齢化により，我々の施設でも，follow しえた 519 例中 20 例（3.2\%）に悪性腫瘍の発生 を認めた。悪性腫瘍を早期発見するために, 患者愁訴を中心にX線, 内視鏡および超音波診断を組み合わせる等の努 カが望まれる. 我々は, 胃癌 5 例をはじめ, 舌癌, 食道癌, 肝細胞癌, 胆囊結腸重複癌, 直腸癌光れぞれ 1 例, 合計 10 例の消化器癌症例に, 致命的合併症もなく根治術を施行しえた。我々は透析患者であるために手術適応を失うこと はないと確信している. しかし, 抗腫瘍剤の投与方法および手術による根治性の追求については, 慢性腎不全关のも のによる予後も考慮に入れる必要があり, 今後の問題であると考えている.

Surgical management of patients on chronic hemodialysis undergoing emergency operations and radical surgery for cancer of the digestive system

Kouji Soeda, M. D., Michio Odaka, M. D., Hiroyuki Hirasawa, M. D.*, Hirotada Kobayashi, M. D., Takao Sugai, M. D., Haruyuki Hayashi, M. D., Susumu Kobayashi, M. D., Noriyoshi Murotani, M. D., Yasushi Itoh, M. D.,Ikuya Oshima, M. D., Kaichi Isono, M. D., Toshitsune Shimada, M. D. **, Shinya Sakurai, M. D. ${ }^{* *}$ and Shigeto Oda, M. D.**

Second Department of Surgery, Department of Emergency and Critical Care Medicine*, Chiba University School of Medicine ; Department of Dialysis Unit, Chiba Shakai Hoken Hospital**

添田 耕司 千葉大学医学部第 2 外科

于 280 千葉市亥鼻 1-8-1 (0472-22-7171) 
Between December, 1966 and June, 1985, 137 hemodialyzed patients underwent 74 elective and 63 emergency operations at our institute. The number of patients who died within one month after emergency surgery was significantly greater than that following elective surgery. Many severe infections and inadequate perioperative management were pointed out in the cases of emergency surgery. Parameters of self-defence mechanisms such as cell-mediated immunity, reticuloendothelial phagocytic index and complement system $\left(\mathrm{C}_{3}, \mathrm{CH} 50\right)$ were evaluated and were found to be depressed among the hemodialysis patients.

Before emergency surgery, hemodialysis using bicarbonate dialyzate and an EVAL membrane dialyzer without heparin was performed with transfusion of packed red blood cells and fresh frozen plasma. The aims of the preoperative dialysis were to ensure maximum metabolic control, to avoid fluid overload and hyperpotassemia and to correct levels of hematocrit and serum protein. After surgery, parenteral nutrition, administration of immunog. lobulin and replacement of opsonic proteins should be done for enhancement of depressed host defence mechanisms. Administration of a biological response modifier, $\mathrm{OK}-432$ were tried in several cases in order to prevent infectious complications. Our perioperative management consists of hemopurification, enhancement of self -defence mechanisms against infection, glucose insulin therapy and parenteral nutrition. The first hemodialysis after surgery was performed successfully on the 3rd postoperative day.

Since 1973, ten radical operations for cancers of the digestive system have been performed without severe complications. The diseases were five cases of gastric cancer and one case each of tongue cancer, esophageal cancer, rectal cancer, hepatocellular carcinoma and gall bladder-colon double cancer, respectively. The numbers of patients of all ages receiving dialysis have been rising considerably recently so that the number of reports on such patients with malignancy will increase. Efforts to rule out the likelihood of malignant disease at an early stage should therefore be made using upper Gl series, ultrasonography and so on. Because of the poor prognosis of chronic renal failure per se, indications for anti-tumor agents and aggressive surgery in these patients should be considered carefully and are still controversial.

\section{はじめに}

慢性透析患者数は，増加の一途を辿るとともに合併症 ないしは併発疾患が増加し，外科手術を要する症例も増 加しており，緊急手術を余儀なくされることも多い.ま た, 1984 年の導入患者平均年齢は 53.2 歳, 透析患者平均 年齢は 49.2 歳であり,ともに癌年齢に達してきてい る ${ }^{1)}$. したがって今後, 透析患者の悪性疾患に対する手術 が増加するものと思われる。一方, 麻酔法の進歩 ${ }^{2}$, 外科 栄養法 ${ }^{3)}$ の発達, 検査の精度の確立と普遍化などにより, 慢性透析患者の外科手術も安全性を増している ${ }^{4,5)}$. しか し，透析患者は一般外科手術患者と異なって種々の特異 点を有しており, 術後経過および術後合併症も, 一般外 科手術症例とは異なっている ${ }^{6 \sim 8)}$.

今回, 我々は, 慢性透析患者の併存病変に対する手術 症例について, 緊急手術の成績, 術後合併症および消化 器癌手術症例の術前術後管理を検討し，さらに透析患者 の感染に対する自己防御機構について一般消化器患者と 比較したので，若干の考察を加え報告する。

\section{対象症例・方法}

1. 慢性透析患者手術症例

千葉大学第 2 外科および千葉社会保険病院において， 1966 年 12 月から 1985 年 6 月までに経験した 1,355 例
の慢性透析患者外科手術例のうち, 併存病変に対する手 術 137 例を対象とした。男性 84 例，女性 53 例で，年齢 は 19 歳から 72 歳まで平均 43.8 歳であった. 全麻症例 59 例, 局麻症例 78 例であり, 併存病変疾患, これに対す る術式および症例数は, 表 1,2 に示す如くであった。 この手術症例に対し, 以下の検索を行った。

1 ）慢性透析患者手術直死例と手術合併症併発例の検 討

手術直死例については, 緊急手術の有無, 死亡までの 日数, 合併症および死因について検討し, 非直死例で合 併症併発例については, 緊急手術の有無および合併症に ついて検討した。

2 ）慢性透析患者の予定手術と緊急手術における直死 率, 術前検査値および術後合併症の比較

予定手術群と緊急手術群において直死率, 術前検查值 および術後合併症について比較検討した. 術前検查の項 目は, ヘマトクリット值, 血清カリウム濃度, 血清総蛋 白量, BUN および血清クレアチニン濃度であった。

2 . 消化器癌手術症例

上記の慢性透析患者手術症例のうち, 1973 年から 1985 年 6 月までに, 我々の施設で経験した消化器癌手術症例 は 10 例あり, 男性 7 例, 女性 3 例であり, 年齢は $42 \sim 69$ 


\begin{tabular}{|c|c|c|c|}
\hline 原疾患 & 術 & 症例数 & 直死例数 \\
\hline 消化器系疾患 & & $51(36)$ & $9(9)$ \\
\hline 舌癌 & 舌部分切除術 & 1 & \\
\hline 食道癌 & $\begin{array}{l}\text { 胸部食道全摘, 噴門切除術 } \\
\text { 胸壁前食道胃吻合術 }\end{array}$ & 1 & \\
\hline 胃癌 & 胃切除術 & 5 & \\
\hline 胆囊癌・結腸癌 & $\begin{array}{l}\text { 胆囊摘出, 胆管合併切除術 } \\
\text { 兼結腸亜全摘出術 }\end{array}$ & 1 & \\
\hline 直腸癌 & 低位前方切除術 & 1 & \\
\hline 肝細胞癌 & 肝外側区域切除術 & 1 & \\
\hline 小腸脂肪腫 & 回腸部分切除術 & 1 & \\
\hline 胃・十二指腸潰瘍 & 胃切除術 & $2(2)$ & \\
\hline 吻合部潰瘍 & 残胃再切除術 & $1(1)$ & $1(1)$ \\
\hline 腹膜炎 & ドレナージ & $7(7)$ & $3(3)$ \\
\hline イレウス & 癋着剝離術 & $5(5)$ & $2(2)$ \\
\hline 虫垂炎 & 虫垂切除術 & $16(16)$ & $1(1)$ \\
\hline 上腸間膜動脈血栓症 & 試験開腹 & $2(2)$ & $2(2)$ \\
\hline 胆囊炎 ～～～～～ & 胆囊摘出術 & $1(1)$ & \\
\hline 腸間膜血腫 & 止血術 & $1(1)$ & \\
\hline 痔核 & 根治術 & $5(1)$ & \\
\hline 泌尿器系疾患 & & $14(2)$ & $1(1)$ \\
\hline 悪性高血圧 & 両.腎摘出術 & 3 & \\
\hline 囊胞腎 & 腎摘出術 & 4 & \\
\hline 腎結石 & 腎摘出術 & 1 & \\
\hline 腎結核・腎水腫 & 腎切開術 & 1 & \\
\hline 膀胱出血 & 膀胱切開 - 骨片除去術 & 2 & $1(1)$ \\
\hline その他 & & 3 & \\
\hline
\end{tabular}

（千大二外・千葉社保 1966.12～1985.6)

（）内は緊急手術例数

表 1 慢性透析患者手術例（併存病変に対する）その 1

歳, 平均 48.9 歳であった。慢性透析を要した疾患は, 慢 性系球体腎炎 4 例, 糖尿病性腎症 4 例, 腎結核 1 例, 慢 性腎孟腎炎 1 例であった。透析歷は 1 力月から 6 年まで であり, 平均 2 年 4 カ月であった。消化器癌は胃癌が 5 例, 舌癌, 食道癌, 胆囊結腸重複癌, 直腸癌および肝細 胞癌が，それぞれ 1 例であった（表 3 ).

1 ) 消化器癌手術症例の術前術後管理の検討

術前に biological response modifier である OK-4329) を皮内に 4 日間, 計 $20 \mathrm{KE}$ を投与し, その前後において, fat emulsion 法による細網内皮系機能 ${ }^{10)}$ を検討した. 次 に, 術中補液量および輸血量, 術後レスピレーター使用 の有無, さらに術後初回透析の, 施行日, 施行方法およ び検查值について検討し, 合併症の有無についても検討 した。

3. 感染に対する自己防御機構に対する検討症例

慢性透析患者 12 例, 消化器系疾患術前患者 11 例にお いて, 感染症に対する自己防御機構のパラメーターの比 較検討を行った。慢性透析患者は, 全例慢性系球体腎炎 であり, 平均透析期間は 4 年 4 力月土 1 年 4 力月（M士
SE) であった. また平均年齢は $42.2 \pm 3.5$ 歳, 尿量は $490 \pm 140 \mathrm{~m} l /$ day で BUN は $62.8 \pm 4.3 \mathrm{mg} / \mathrm{d} l$ であっ た. 消化器系良性疾患術前患者は, 胆石症等の非感染症 症例であり, 平均年齢が $46.7 \pm 4.0$ 歳, 尿量が $1,640 \pm 140$ $\mathrm{m} l /$ day でBUN は $12.7 \pm 0.5 \mathrm{mg} / \mathrm{d} l$ であった。尿量お よび BUN において両群間に差を認めたが, 平均年齢に 差は認めなかった。

1) 慢性透析患者と消化器系術前患者における感染に 対する自己防御機構のパラメーターの比較検討

比較するパラメーターは, 末梢白血球数,ヘマトクリッ 卜值, 血清総蛋白量, skin test による細胞性免疫能 ${ }^{11)}$, fat emulsion 法による細胞内皮系貪食能, 血清免疫グロ ブリン值 (IgG, IgA, IgM), 血清補体值 $\left(\mathrm{C}_{3}, \mathrm{C}_{4}\right)$ および 補体価 CH50 である. skin test はカンジタ, PPD, SKSD の 3 種抗原を用い, 接種後 48 時間目に計測し, 発赤の長 径 $5 \mathrm{~mm}$ 以上を陽性とし，2 種以上の抗原に対し陽性で あったものを normal, 1 種の抗原のみ陽性であったも のを relative anergy，3種すべてに対し陰性であったも のを anergy と， 3 群に分類した。 fat emulsion 法によ 
る細網内系貪食能測定は，10\% lipid emulsion $50 \mathrm{~m} l$ を 一側上肢より 2 分間で静注し, 静注後 2 分間隔で反対側

\begin{tabular}{|c|c|c|c|}
\hline 原疾患 & 術式 & 症例数 & 直死例数 \\
\hline 心脈管系疾患 & & $19(18)$ & $3(3)$ \\
\hline $\begin{array}{l}\text { 心包炎・心タンポナーデ } \\
\text { 腋窩動脈瘤 } \\
\text { 鎖骨下静脈血栓症 }\end{array}$ & $\begin{array}{l}\text { 心包ドレナージ } \\
\text { 上肢切断術 } \\
\text { 血栓除去術 }\end{array}$ & $\begin{array}{r}17 \\
1 \\
1 \\
1(1)\end{array}$ & $3(3)$ \\
\hline 脳神経外科的疾患 & & $3(3)$ & $1(1)$ \\
\hline 硬膜下（外）血腫 & 開頭術 & $3(3)$ & $1(1)$ \\
\hline 整形外科的疾患 & & $12(2)$ & $2(2)$ \\
\hline $\begin{array}{l}\text { 大腿骨頝部骨折 } \\
\text { 手根管症候群 } \\
\text { その他 }\end{array}$ & $\begin{array}{l}\text { 人工骨頭置換術 } \\
\text { 根治術 }\end{array}$ & $\begin{array}{l}4 \\
3 \\
5(2)\end{array}$ & $2(2)$ \\
\hline 産婦人科的疾患 & & 8 & \\
\hline $\begin{array}{l}\text { 子宮癌 } \\
\text { 子宮筋腫 } \\
\text { 子宮内膜症 } \\
\text { 卵巣癌 } \\
\text { 妊娠 } \\
\text { その他 }\end{array}$ & $\begin{array}{l}\text { 子宮全摘出術 } \\
\text { 膣上部切断術 } \\
\text { 臸上部切断術 } \\
\text { 摘出術 } \\
\text { 帝王切開 }\end{array}$ & $\begin{array}{l}1 \\
2 \\
1 \\
1 \\
1 \\
2\end{array}$ & \\
\hline 眼科系疾患 & & 11 & \\
\hline $\begin{array}{l}\text { 白内障 } \\
\text { 網膜剝離 }\end{array}$ & $\begin{array}{l}\text { レンズ摘出術 } \\
\text { ジアテルミー }\end{array}$ & $\begin{array}{l}9 \\
2 \\
-\end{array}$ & \\
\hline その他 & & $19(1)$ & \\
\hline 合計 & & $137(63)$ & $16(16)$ \\
\hline
\end{tabular}

(千大二外・千葉社保 1966.12１985.6)

（）内は緊急手術例数

表 2 慢性透析患者手術例（併存病変に対する）その 2
上肢より 5 回採血, 分光光度計を用い, $580 \mathrm{~nm}$ の波長で 血漿の混濁度を測定し, 各時間での測定值より lipid emulsion の血中半減期を求め, $\log 2 /$ 半減期の式より phagocytic index を算出した。

諸データーの統計学的分析には， $\mathrm{X}^{2}$ 検定あるいは，各 群の mean $\pm \mathrm{SE}$ を求め, Student's $\mathrm{t}$ 検定を用いて行っ た。

\section{結果}

1. 慢性透析患者手術直死例と手術合併症併発例の検 討

慢性透析患者手術直死例は 16 例あり, 全例緊急手術例 であった（表 4). 直死例の原疾患を分けると，1）感染 に属するもので，消化管穿孔等による汎発性腹膜炎 6 例 と骨䯣感染 2 例の計 8 例があり，2）ショックに属する もので，心タンポナーデ 3 例と上腸間膜動脈血栓症 2 例 の計 5 例がありさらに， 3 ）出血に属するもので頭蓋内 出血 1 例, 吻合部潰瘍出血 1 例, 骨盤カリエス膀胱出血 1 例の 3 例があり 3 群に分かれ，4）悪性疾患に属する 症例はなかった。

死因を検討すると,感染に属した症例はもちろんだが, 上腸間膜動脈血栓症の 2 例と吻合部潰瘍の 1 例も, 敗血 症および汎発性腹膜炎となり, septic multiple organ failure (MOF) にて死亡していた。術後合併症としては, 術当日死亡例を除く 9 例に合併症を認め, その内訳は敗 血症 7 例, 肺合併症 3 例であった.

次に，術後合併症を有した非直死例を検討すると，緊 急手術 4 例, 予定手術 6 例であり, 術後合併症は血清力 リウム值 $6.0 \mathrm{mEq} / l$ 以上となった高カリウム血症 4 例,

\begin{tabular}{|c|c|c|c|c|c|c|c|c|c|c|}
\hline No. & 症例 & 年齢(歳) & 性 & 年度 & 原疾患 & 透析歴 & 消化器癌 & 術式 & 進行度 & 転帰 \\
\hline 1 & & 42 & 男 & 1973 & CGN & 1 年 5 力月 & 舌癌 & 舌部分切除 & 早期癌 & 8 年他病死 \\
\hline 2 & & 69 & 男 & 1978 & DN & 1 年 6 力月 & 胃癌 & 胃切除·大網切除 $(\mathrm{BI})$ & 進行癌 & 1 年 1 力月癌死 \\
\hline 3 & & 42 & 男 & 1978 & CGN & 4 年 5 力月 & 食道癌 & $\begin{array}{c}\text { 胸部食道全摘，噴門切除 } \\
\text { 胸壁前食道胃吻合術 }\end{array}$ & 早期癌 & 3 年他病死 \\
\hline 4 & & 59 & 女 & 1978 & CGN & 5 年 & 胃癌 & 胃切除・大網切除 (B II) & 進行癌 & 6 力月癌死 \\
\hline 5 & & 62 & 男 & 1980 & CGN & 2 年 & 直腸癌 & 低位前方切除 & 進行癌 & 4 年 3 力月生 \\
\hline 6 & & 60 & 男 & 1983 & 腎結核 & 4 力月 & 胃癌 & 胃切除·大網切除 (B I ) & 早期癌 & 2 年生 \\
\hline 7 & & 55 & 男 & 1984 & $\mathrm{DN}$ & 1 力月 & 胃癌 & 胃切除·大網切除 (B II) & 早期癌 & 1 年生 \\
\hline 8 & & 40 & 女 & 1984 & 腎孟腎炎 & 6 年 & $\begin{array}{l}\text { 胆囊癌 } \\
\text { 結腸癌 }\end{array}$ & $\begin{array}{c}\text { 胆囊摘出, 胆管合併切除 } \\
\text { 結腸亚全摘出 }\end{array}$ & 進行癌 & 7 力月生 \\
\hline 9 & & 59 & 女 & 1985 & DN & 1 年 1 力月 & 胃癌 & 胃切除·大網切除 (B II) & 早期癌 & 2 力月生 \\
\hline 10 & & 51 & 男 & 1985 & DN & 1 年 3 力月 & 肝細胞癌 & 肝外側区域切除 & 進行癌 & 1 力月生 \\
\hline
\end{tabular}

（千大二外・千葉社保 1973～1985.6)

CGN : 慢性系球体腎炎, DN : 糖尿病性腎症

B : Billroth 法

表 3 慢性透析患者消化器癌手術症例 


\begin{tabular}{|c|c|c|c|c|c|c|c|c|c|}
\hline No. & 症例 & 年齢 & 性 & 原疾患 & 術式 & 麻酔 & $\begin{array}{c}\text { 死亡まで } \\
\text { の日数 }\end{array}$ & 合併症 & 死因 \\
\hline 1 & & 51 & 男 & 汎発性腹膜炎 & ドレナージ & 全 & 7 & 敗血症 & MOF \\
\hline 2 & & 28 & 男 & 虫垂穿孔 & 虫切, ドレナージ & 全 & 9 & 敗血症 & MOF \\
\hline 3 & & 31 & 男 & 小腸重積症 & 重積解離術 & 全 & 0 & - & MOF \\
\hline 4 & & 26 & 男 & 心包炎・心タンポナーデ & 心包ドレナージ & 局 & 4 & 消化管出血 & 心不全 \\
\hline 5 & & 35 & 女 & 十二指腸潰瘍穿孔 & 膿瘍摘出ドレナージ & 全 & 7 & 敗血症 & MOF \\
\hline 6 & & 19 & 女 & イレウス & 痛着剝離術 & 全 & 13 & $\begin{array}{c}\text { 敗血症 } \\
\text { 肺合併症 }\end{array}$ & MOF \\
\hline 7 & & 24 & 男 & 吻合部潰瘍出血 & 残胃再切除 & 全 & 10 & $\begin{array}{l}\text { 縫合不全 } \\
\text { 肺合併症 } \\
\text { 創部感染 }\end{array}$ & MOF \\
\hline 8 & & 18 & 男 & 心包炎・心タンポナーデ & 心包ドレナージ & 局 & 0 & - & 心不全 \\
\hline 9 & & 54 & 男 & 上腸間膜動脈血栓症 & 試験開腹 & 全 & 0 & - & MOF \\
\hline 10 & & 38 & 女 & 脳挫傷急性硬膜下血腫 & 穿頭術 & 全 & 0 & - & 脳挫傷 \\
\hline 11 & & 34 & 男 & 骨盤カリエス膀胱出血 & 外腸骨動脈結禁 & 全 & 0 & - & $\begin{array}{l}\text { 出血性 } \\
\text { ショック }\end{array}$ \\
\hline 12 & & 54 & 男 & 心包炎・心夕ンポナーデ & 心包ドレナージ & 局 & 0 & - & 心不全 \\
\hline 13 & & 47 & 男 & 頝椎膿瘍 & ドレナージ & 局 & 4 & 敗血症 & MOF \\
\hline 14 & & 54 & 男 & 化膿性膝関節炎 & ドレナージ・滑膜切除 & 局 & 2 & 敗血症 & MOF \\
\hline 15 & & 50 & 男 & 上腸間膜動脈血栓症 & 試験開腹 & 全 & 0 & - & MOF \\
\hline 16 & & 72 & 女 & $\begin{array}{l}\text { 虫垂炎術後 } \\
\text { 腹膜炎 }\end{array}$ & ドレナージ & 全 & 7 & $\begin{array}{c}\text { 敗血症 } \\
\text { 高 } \mathrm{K} \text { 血症 } \\
\text { 肺合併症 } \\
\text { 創部感染 }\end{array}$ & MOF \\
\hline
\end{tabular}

表 4 慢性透析患者手術直死例（全例緊急手術例）

不整脈 4 例，創部感染 2 例，blood access 閉塞 2 例およ び肺合併症 2 例であった（表 5 ).

2. 慢性透析患者の予定手術と緊急手術における直死 率, 術前検査值および術後合併症の比較

137 例中予定手術は 74 例（全麻 36 例，局麻 38 例）で あり, 緊急手術は 63 例 (全麻 23 例, 局麻 40 例) であっ た。予定手術には直死例はなく, 緊急手術群で全麻例で $47.8 \%$, 局麻例で $12.5 \%$ 直死率を示し, 全麻および局 麻とも, 緊急手術群では子定手術群に比し, 有意に $(\mathrm{P}<$ 0.05 および $\mathrm{P}<0.01$ ) 直死率は高かうた（表 6 ).

次に予定手術群 21 例と, 緊急手術群 27 例の術前検査 值を比較すると, 血清総蛋白量には差は認められないが, 血清カリウム, BUN および血清クレアチニン濃度にお いて，緊急手術群では予定手術群に比して有意に（ $\mathrm{P}<$ 0.05 および $\mathrm{P}<0.01)$ 高く，逆にへマトクリットにおい ては有意に（ $\mathrm{P}<0.01 ）$ 低かった（表 7$)$.

術後合併症について検討すると, 敗血症 7 例 (5.1\%), 肺合併症 5 例 $(3.6 \%)$, 創部感染 4 例 $(2.9 \%)$, 縫合不
全 1 例 $(0.7 \%)$, 感染症にまつわる合併症が多かった。 このうち肺合併症 1 例を除く全例が緊急手術例であり, 合併症を有した 19 例中, これらの感染症に関わる合併症 を有した症例は 13 例で $68.4 \%$ を占めた。一方, 高力リウ 厶血症 5 例, 不整脈 4 例, blood access の閉塞 2 例等の 合併症は, 慢性透析患者手術症例に特有な合併症であり, 緊急手術抢よび予定手術の双方に認められるが，これら の合併症にて死亡することはなかった（表 8 ).

3 . 消化器癌手術症例の術前術後管理の検討

4 例に OK-432, $20 \mathrm{KE}$ を術前に投与した。このうち 3 例は, fat emulsion 法による細網内皮系貪食能は増加 したが, 残りの 1 例は減少しており,この症例に肺合併 症が認められた. 術中出血量 $514 \pm 101 \mathrm{~g}$ に対し, 輸血量 は $469 \pm 139 \mathrm{~m} l$ 行ったが, 最近の 4 例は新鮮凍結血漿 (FFP) を中心に投与している. 術中輸液量は, 平均手術 時間 3 時間 48 分に対し, $1,189 \pm 229 \mathrm{ml}$ であり, 時間お よび体重あたり $6.3 \mathrm{~m} l / \mathrm{kg} / \mathrm{h}$ であった（表 9 ).レスピ レーターは, 食道癌, 胃癌, 胆囊結腸重複癌, 肝細胞癌 


\begin{tabular}{|c|c|c|c|c|c|c|c|c|}
\hline No. & 症例 & 年齢 & 性 & 原疾患 & 術式 & 麻酔 & $\begin{array}{l}\text { 緊急 } \\
\text { 手術 }\end{array}$ & 合併症 \\
\hline 1 & & 22 & 男 & 悪性高血圧 & $\begin{array}{l}\text { 両腎摘出術 } \\
\text { 脾摘出術 }\end{array}$ & 全 & $(-)$ & 高 K血症 \\
\hline 2 & & 47 & 男 & イレウス & 癒着剝離術 & 全 & $(+)$ & $\begin{array}{l}\text { 高 K血症 } \\
\text { 創部感染 }\end{array}$ \\
\hline 3 & & 42 & 男 & 胆囊炎 & 胆囊摘出術 & 全 & $(+)$ & $\begin{array}{c}\text { 不整脈 } \\
\text { 創部感染 }\end{array}$ \\
\hline 4 & & 48 & 男 & 囊胞腎 & 右腎摘出術 & 全 & $(-)$ & $\begin{array}{l}\text { 高 K血症 } \\
\text { 不整脈 }\end{array}$ \\
\hline 5 & & 37 & 女 & 大腿骨頝部骨折 & $\begin{array}{l}\text { 人工骨頭置 } \\
\text { 換術 }\end{array}$ & 全 & $(-)$ & $\begin{array}{c}\text { blood access } \\
\text { 閉塞 }\end{array}$ \\
\hline 6 & & 46 & 男 & 出血性胃潰瘍 & 胃切除術 & 全 & $(+)$ & $\begin{array}{l}\text { 肺合併症 } \\
\text { 不整脈 }\end{array}$ \\
\hline 7 & & 38 & 女 & 人工骨頭置換部膿瘍 & 膿瘍切除術 & 全 & $(-)$ & 高 K血症 \\
\hline 8 & & 51 & 女 & 卵巣癌イレウス & $\begin{array}{l}\text { 回腸結腸 } \\
\text { 吻合術 }\end{array}$ & 全 & $(+)$ & $\begin{array}{c}\text { blood access } \\
\text { 閉塞 }\end{array}$ \\
\hline 9 & & 67 & 女 & 白内障 & レンズ摘出術 & 局 & $(-)$ & 不整脈 \\
\hline 10 & & 39 & 女 & 胆囊•結腸重複癌 & $\begin{array}{l}\text { 胆囊摘出術 } \\
\text { 胆管合併切除 } \\
\text { 術・結腸亜全 } \\
\text { 摘出術 }\end{array}$ & 全 & $(-)$ & 肺合併症 \\
\hline
\end{tabular}

表 5 慢性透析患者手術合併症併発例（全例非直死例）

\begin{tabular}{|c|c|c|c|c|}
\hline & \multicolumn{2}{|c|}{ 全麻手術例 } & \multicolumn{2}{|c|}{ 局麻手術例 } \\
\hline & 症例数 & 直死例数 & 症例数 & 直死例数 \\
\hline 予定手術群 & 36 & $0 \quad 7$ & 38 & $0 \quad 7$ \\
\hline 緊急手術群 & 23 & $\begin{array}{l}\mathrm{p}<0.01 \\
11 \\
(47.8 \%)\end{array}$ & 40 & $\begin{array}{l}\mathrm{p}<0.05 \\
5 \\
(12.5 \%)\end{array}$ \\
\hline
\end{tabular}

表 6 透析患者の予定手術と緊急手術の直死率の比 較 (千大二外・千葉社保)

（）内は直死率

\begin{tabular}{c|c|c|c|c|c|c}
\hline & $\begin{array}{c}\text { ヘマトクリット } \\
(\%)\end{array}$ & $\begin{array}{c}\text { 血清カリウム } \\
(\mathrm{mEq} / l)\end{array}$ & $\begin{array}{c}\text { 血清総蛋白 } \\
(\mathrm{g} / \mathrm{d} l)\end{array}$ & $\begin{array}{c}\mathrm{BUN} \\
(\mathrm{mg} / \mathrm{d} l)\end{array}$ & $\begin{array}{c}\text { 血清クレアチニン } \\
(\mathrm{mg} / \mathrm{d} l)\end{array}$ \\
\hline $\begin{array}{c}\text { 予定手術群 } \\
(\mathrm{n}=21)\end{array}$ & $28.8 \pm 1.8$ & $4.2 \pm 0.27$ & $7.2 \pm 0.2$ & $42.0 \pm 5.5$ & $6.5 \pm 0.9$ \\
\hline $\begin{array}{c}\text { 緊急手術群 } \\
(\mathrm{n}=27)\end{array}$ & $19.8 \pm 1.6$
\end{tabular}

$※ \mathrm{p}<0.05, \approx \% \mathrm{p}<0.01$

表 7 予定手術群と緊急手術群の術前検査值の比較 $(\mathrm{M} \pm \mathrm{SE})$

の各 1 例に, 術後 5 〜 18 時間使用した. glucose-insulin (GI) 療法を 9 例に平均 3 日間施行した. 初回透析は, 平 均第 3 病日であり, 局所へパリン化法で 6 例, ヘパリン
300 単位のプライミングによる EVAL 膜透析で 4 例に 施行した. 初回透析時の検査值は, ヘマトクリット值 $26.1 \pm 1.4 \%$, 血清カリウム值 $4.5 \pm 0.2 \mathrm{mEq} / l$, 血清総蛋 


\begin{tabular}{l|c|c|c}
\hline 術後合併症 & $\begin{array}{c}\text { 手術 } 137 \text { 例中 } \\
\text { 合併症併発例数 }\end{array}$ & $\begin{array}{c}\text { 予定手術 } 74 \text { 例中 } \\
\text { 合併症併発例数 }\end{array}$ & $\begin{array}{c}\text { 緊急手術 63例中 } \\
\text { 合併症併発例数 }\end{array}$ \\
\hline 1. 敗血症 & $7^{*}$ & 0 & $7^{*}$ \\
2 . 肺合併症 & 5 & 1 & 4 \\
3. 高力リウム血症 & 5 & 3 & 2 \\
4 . 創部感染 & 4 & 0 & 4 \\
5. 不整脈 & 4 & 2 & 2 \\
6. Blood access の閉塞 & 2 & 1 & 1 \\
7. 縫合不全 & $1^{*}$ & 0 & $1^{*}$ \\
8. 消化管出血 & 1 & 0 & 1 \\
\hline
\end{tabular}

* 合併症が死因となった症例

表 8 予定手術群と緊急手術群の術後合併症併発例数の比較

\begin{tabular}{|c|c|c|c|c|c|c|c|c|c|c|c|c|}
\hline \multirow{2}{*}{ No } & \multirow{2}{*}{$\begin{array}{l}\text { 年齢 } \\
\text { (歳) }\end{array}$} & \multirow{2}{*}{ 性 } & \multirow{2}{*}{ 消化器癌 } & \multirow{2}{*}{$\begin{array}{l}\mathrm{OK} 432 \\
\text { 投与量 }\end{array}$} & \multicolumn{2}{|c|}{ RES 機能 } & \multirow{2}{*}{ 麻酔 } & \multirow{2}{*}{ 手術時間 } & \multicolumn{3}{|c|}{ 術中 } & \multirow{2}{*}{ 合併症 } \\
\hline & & & & & OK投与前 & $\mathrm{OK}$ 投与後 & & & 補液量 & 出血量 & 輪血量 & \\
\hline 1 & 42 & 男 & 舌癌 & $(-)$ & & & 局 & $30^{\prime}$ & $50 \mathrm{ml}$ & $30 \mathrm{~g}$ & $0 \mathrm{~m} l$ & $(-)$ \\
\hline 2 & 69 & 男 & 胃癌 & $(-)$ & & & GOF & $2^{\circ} 20^{\prime}$ & $400 \mathrm{~m} l$ & $510 \mathrm{~g}$ & $400 \mathrm{ml}$ & $(-)$ \\
\hline 3 & 42 & 男 & 食道癌 & $(-)$ & & & GOF & $5^{\circ} 25^{\prime}$ & $2400 \mathrm{~m} l$ & $970 \mathrm{~g}$ & $1000 \mathrm{~m} l$ & $(-)$ \\
\hline 4 & 59 & 女 & 胃癌 & $(-)$ & & & GOF & $3^{\circ} 10^{\prime}$ & $1350 \mathrm{~m} l$ & $760 \mathrm{~g}$ & $600 \mathrm{~m} l$ & $(-)$ \\
\hline 5 & 62 & 男 & 直腸癌 & $(-)$ & & & GOF & $1^{\circ} 50^{\prime}$ & $600 \mathrm{ml}$ & $210 \mathrm{~g}$ & $0 \mathrm{~m} l$ & $(-)$ \\
\hline 6 & 60 & 男 & 胃癌 & $(-)$ & & & GOF & $2^{\circ} 50^{\prime}$ & $1170 \mathrm{~m} l$ & $270 \mathrm{~g}$ & $0 \mathrm{~m} l$ & $(-)$ \\
\hline 7 & 55 & 男 & 胃癌 & $20 \mathrm{KE}$ & 0.0139 & 0.0160 & GOF & $4^{\circ} 05^{\prime}$ & $1800 \mathrm{~m} l$ & $440 \mathrm{~g}$ & $\begin{array}{l}\text { FFP } \\
\qquad 400 \mathrm{~m} l\end{array}$ & $(-)$ \\
\hline 8 & 40 & 女 & $\begin{array}{l}\text { 胆灢癌 } \\
\text { 結腸癌 }\end{array}$ & $20 \mathrm{KE}$ & 0.0155 & 0.0117 & GOF & $8^{\circ} 40^{\prime}$ & $2200 \mathrm{~m} l$ & $1090 \mathrm{~g}$ & FFP $\begin{array}{r}220 \mathrm{~m} l \\
1200 \mathrm{~m} l\end{array}$ & 肺合併症 \\
\hline 9 & 59 & 女 & 胃癌 & $20 \mathrm{KE}$ & 0.0171 & 0.0205 & GOF & $4^{\circ} 05$ & $900 \mathrm{~m} l$ & $520 \mathrm{~g}$ & $\begin{array}{ll} & 200 \mathrm{~m} l \\
& \mathrm{FFP} \\
& \\
& \end{array}$ & $(-)$ \\
\hline 10 & 51 & 男 & 肝細胞癌 & $20 \mathrm{KE}$ & 0.0175 & 0.0209 & GOẼ & $5^{\circ} 05^{\prime}$ & $1020 \mathrm{~m} l$ & $340 \mathrm{~g}$ & $265 \mathrm{~m} l$ & $(-)$ \\
\hline \multicolumn{4}{|c|}{ 平均 $(\mathrm{M} \pm \mathrm{SE})$} & & $\begin{array}{c}0.0160 \\
\pm 0.0007 \\
(\mathrm{n}=4)\end{array}$ & $\begin{array}{c}0.0173 \\
\pm 0.0019 \\
(\mathrm{n}=4)\end{array}$ & & $\begin{array}{l}3{ }^{\circ} 48^{\prime} \\
\pm 41^{\prime}\end{array}$ & $1189 \pm 229 \mathrm{~m} l$ & $514 \pm 101 \mathrm{~g}$ & $469 \pm 139 \mathrm{~m} l$ & \\
\hline
\end{tabular}

表 9 慢性透析患者消化器癌手術症例の術前術中経過と術後合併症

白量 $6.1 \pm 0.2 \mathrm{~g} / \mathrm{d} l, \mathrm{BUN}$ 濃度 $71.3 \pm 5.9 \mathrm{mg} / \mathrm{d} l$, 血清クレ アチニン濃度 $9.5 \pm 0.6 \mathrm{mg} / \mathrm{d} l$ であった（表 $10 ）$.

4. 慢性透析患者と消化器系手術患者における感染に 対する自己防御機構のパラメーターの比較検討

慢性透析患者 (透析群) と消化器系手術患者（消化器 群）とを比較すると，それぞれ末梢白血球数は，5,000土 $400 / \mathrm{mm}^{3}, 5,300 \pm 360 / \mathrm{mm}^{3}$, ヘマトクリット值は $20.8 \pm$ $1.0 \%, 37.9 \pm 1.3 \%$ ，血清総蛋白量は， $6.6 \pm 1.6 \mathrm{~g} / \mathrm{d} l, 7$. $2 \pm 0.1 \mathrm{~g} / \mathrm{d} l$ であった.へマトクリット值に差 $(\mathrm{P}<$ 0.005)が認められたが, 未梢白血球および血清総蛋白量 には差がなかった。 skin test による細胞性免疫能をみる
と, 透析群には anergy および relative anergy が $45 \%$ に認められ, normal 患者の割合は透析群では消化器群 に比して有意に（ $\mathrm{p}<0.01 ）$ 低かった. fat emulsion 法 による細網内皮系貪食能をみると, 透析群 $0.0161 \pm$ 0.0007 , 消化器群 $0.250 \pm 0.0017$ であり, 透析群では消 化器群に比し有意に $(\mathrm{p}<0.005)$ 低下していた（図 1$)$. 血清免疫グロブリン值は, 透析群および消化器群, それ ぞれ IgG が $1,367 \pm 74 \mathrm{mg} / \mathrm{d} l, 1,381 \pm 77 \mathrm{mg} / \mathrm{d} l, \operatorname{IgA}$ が $156 \pm 13 \mathrm{mg} / \mathrm{d} l, 225 \pm 21 \mathrm{mg} / \mathrm{d} l, I g M$ が $127 \pm 26 \mathrm{mg} / \mathrm{d} l$, $152 \pm 19 \mathrm{mg} / \mathrm{d} l$ であり, 両群に差は認められなかった。 血清補体值を検討すると, 透析群および消化器群それぞ 


\begin{tabular}{|c|c|c|c|c|c|c|c|c|c|c|c|c|c|c|}
\hline \multirow[b]{2}{*}{ No } & \multirow[b]{2}{*}{$\begin{array}{l}\text { 年歯 } \\
\text { (歳) }\end{array}$} & \multirow{2}{*}{ 性 } & \multirow[b]{2}{*}{ 消化器癌 } & \multirow[b]{2}{*}{$\begin{array}{l}\text { 術後レス } \\
\text { ピレーター }\end{array}$} & \multirow{2}{*}{$\begin{array}{c}\text { 術後 } \\
1 \text { 日尿量 }\end{array}$} & \multirow{2}{*}{$\begin{array}{c}\text { GI } \\
\text { 療法 }\end{array}$} & \multicolumn{3}{|c|}{ 術後初回透析 } & \multicolumn{5}{|c|}{ 術後初回透析時検査值 } \\
\hline & & & & & & & 透析日 & $\begin{array}{l}\text { ダイア } \\
\text { ライザー }\end{array}$ & $\begin{array}{l}\text { ヘハリン } \\
\text { 投与法 }\end{array}$ & $\begin{array}{l}\text { Hct } \\
(\%)\end{array}$ & $\begin{array}{c}\mathrm{s}-\mathrm{K} \\
(\mathrm{mEq} / l)\end{array}$ & $\begin{array}{c}\mathrm{TP} \\
(\mathrm{g} / \mathrm{d} l)\end{array}$ & $\begin{array}{c}\mathrm{BUN} \\
(\mathrm{mg} / \mathrm{d} l)\end{array}$ & $\begin{array}{c}\mathrm{s}-\mathrm{Cr} \\
(\mathrm{mg} / \mathrm{d} l)\end{array}$ \\
\hline 1 & 42 & 男 & 舌癌 & $(-)$ & $0 \mathrm{~m} l$ & $(-)$ & 第 2 病日 & $\mathrm{EX}-03$ & 局所 & 20.0 & 5.3 & 6.9 & 65 & 12.9 \\
\hline 2 & 69 & 男 & 胃癌 & $(-)$ & $800 \mathrm{~m} l$ & 5 日 & 第 3 病日 & $\mathrm{C}-50$ & 局所 & 23.2 & 3.7 & 5.9 & 72 & 8.1 \\
\hline 3 & 42 & 男 & 食道癌 & 16 時間 & $0 \mathrm{~m} l$ & 5 日 & 第 3 病日 & $\mathrm{C}-50$ & 局所 & 27.2 & 5.4 & 5.1 & 50 & 9.5 \\
\hline 4 & 59 & 女 & 胃癌 & $(-)$ & $200 \mathrm{~m} l$ & 5 日 & 第 3 病日 & $C-50$ & 局所 & 34.0 & 5.1 & 5.4 & 84 & 10.1 \\
\hline 5 & 62 & 男 & 直腸癌 & $(-)$ & $100 \mathrm{ml}$ & 5 日 & 第 3 病日 & $\mathrm{C}-40$ & 局所 & 24.4 & 5.1 & 5.9 & 96 & 11.8 \\
\hline 6 & 60 & 男 & 胃癌 & 5 時間 & $1200 \mathrm{ml}$ & 3 日 & 第 3 病日 & C-35 & 局所 & 29.2 & 3.9 & 7.1 & 108 & 11.5 \\
\hline 7 & 55 & 男 & 胃癌 & $(-)$ & $1000 \mathrm{~m} l$ & 2 日 & 第 2 病日 & KF 101 & $\begin{array}{c}300 \text { 単位 } \\
\text { プライミング }\end{array}$ & 26.0 & 4.3 & 5.8 & 52 & 8.0 \\
\hline 8 & 40 & 女 & \begin{tabular}{|l} 
胆囊癌 \\
結腸癌
\end{tabular} & 16 時間 & $0 \mathrm{~m} l$ & 2 日 & 第 2 病日 & KF 101 & $\begin{array}{c}300 \text { 単位 } \\
\text { プライミング }\end{array}$ & 20.3 & 3.9 & 6.5 & 66 & 7.7 \\
\hline 9 & 59 & 女 & 胃癌 & $(-)$ & $800 \mathrm{~m} l$ & 4 日 & 第 4 病日 & KF 201 & $\begin{array}{c}300 \text { 単位 } \\
\text { プライミング }\end{array}$ & 24.3 & 3.7 & 5.8 & 50 & 7.4 \\
\hline 10 & 51 & 男 & 肝細胞癌 & 18 時間 & $50 \mathrm{~m} l$ & 3 日 & 第 3 病日 & KF 201 & $\begin{array}{c}300 \text { 単位 } \\
\text { プライミング }\end{array}$ & 32.4 & 4.4 & 6.9 & 70 & 8.2 \\
\hline & 平均 & $\left(\mathrm{M}_{-}\right.$ & $\pm \mathrm{SE})$ & & $\begin{array}{c}415 \\
\pm 143 \mathrm{~m} l\end{array}$ & $\begin{array}{c}3.4 \\
\pm 0.5 \\
\text { 日 }\end{array}$ & $\begin{array}{r}\text { 第 } 2.8 \\
\pm 0.2 \\
\text { 病日 }\end{array}$ & & & $\begin{array}{l}26.1 \\
\pm 1.4\end{array}$ & $\begin{array}{l}4.5 \\
\pm 0.2\end{array}$ & $\begin{array}{c}6.1 \\
\pm 0.2\end{array}$ & $\begin{array}{l}71.3 \\
\pm 5.9\end{array}$ & $9.5 \pm 0.6$ \\
\hline
\end{tabular}

表 10 慢性透析患者消化器癌手術症例の術後経過と術後初回透析

1）Skin Testによる細胞性免疫能

\begin{tabular}{c|cc|c} 
& \multicolumn{2}{|c|}{ 慢性透析患者 $(\%)$} & 消化器系手術患者 $(\%)$ \\
\hline Anergy & 5 & $(22.5 \%)$ & 0 \\
\hline Relative Anergy & 5 & $(22.5)$ & 0 \\
\hline Normal & $12 *(55.0)$ & $11(100 \%)$ \\
\hline & 22 & 11 \\
& $+P<0.01$ 消化器系手術患者に比較して
\end{tabular}

\section{2）細網内皮系貫食能}

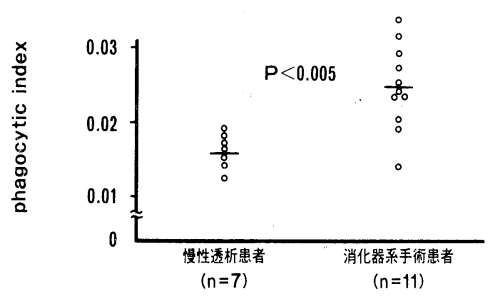

図 1 慢性透析患者と消化器手術患者との感染に対する 自己防御機構の各種パラメーターの比較 (1)
れ, $\mathrm{C}_{3}$ が $46.1 \pm 3.8 \mathrm{mg} / \mathrm{d} l, 85.7 \pm 7.6 \mathrm{mg} / \mathrm{d} l, \mathrm{C}_{4}$ が 22. $6 \pm 2.0 \mathrm{mg} / \mathrm{d} l, 26.2 \pm 1.6 \mathrm{mg} / \mathrm{d} l$ であった. $\mathrm{C}_{3}$ は透析群に おいて消化器群に比し有意に $(\mathrm{p}<0.005)$ 減少していた が， $\mathrm{C}_{4}$ に差は認められなかった。補体価に扔いては，透 析群 $22.9 \pm 3.0$ unit, 消化器群 $34.5 \pm 1.5$ unit であり, 透 析群では消化器群に比し有意に $(\mathrm{P}<0.005)$ 減少してい
3）血清免疫グロブリン値
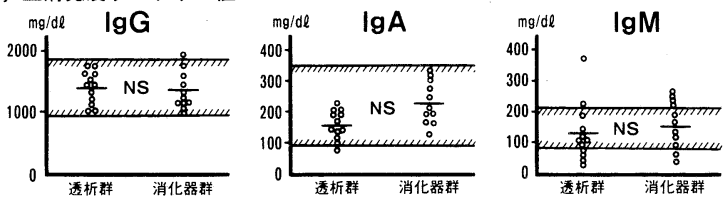

4）血清補体値及び補体価
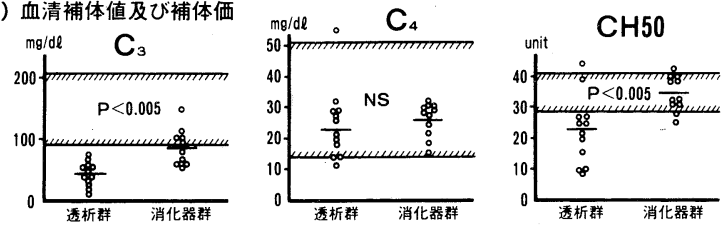

図 2 慢性透析患者と消化器手術患者との感染に対する 自己防御機構の各種パラメーターの比較 (2) 透析群: 慢性透析患者 $(n=12)$

消化器群: 消化器系手術患者 $(n=11)$

た(図 2 )。

以上より, 透析群では消化器群に比し, 細胞性免疫能 の低下，細網内皮系貪食能の低下および補体系の低下を 認めた。

考案

慢性透析患者併存病変に対する手術の直死率は，予定 
手術に比し緊急手術において有意に高く，その直死例全 例が緊急手術例であった。緊急手術直死例の病態を検討 すると，1) 上腸間膜動脈血栓症, 脳挫傷, 心夕ンポナー デ等の致死的な疾患群, 2 ) 沉発性腹膜炎, 頝椎膿瘍等 の重症感染症を有する疾患群, さらに 3 ) 吻合部潰瘍出 血, 腸閉塞, 虫垂炎等の重症感染症を呈してはいないが, 合併症により septic MOF に至り死亡する疾患群の 3 群 に分けられる。

これらの症例に対する対策を我々は次のように考えて いる，1）の致命的な疾患群については, 早期に病変お よび病態を把握することが肝腎である。透析中あるいは 透析後, 腹痛を訴える症例は多いが, この中から虚血性 腸疾患を早期発見することは難しい。しかし，持続性低 血圧, 透析時高度の血圧降下, 高度の動脈硬化および器 質性心疾患等の risk factor を有し, 腹部虚血発作によ ると思われる腹痛を反復する患者をチェックしておき, この患者が, 腹部膨隆あるいは筋性防御等の腹部所見を 呈し，血性軟便あるいは発熱，嘔吐の症状があり，白血 球増多症抢よび腹部単純 X線異常ガス像を認めた場合 は，ただちに開腹する必要があると考える，心包炎は最 近減少しているが,十分な透析と地道な follow が何より の予防策と考える ${ }^{13,14)}$.

次に 2 ) の重症感染症を有する疾患群についても, 重 症感染症に至るまでの対策が重要であることはもちろん だが, 外科的に感染症のコントロールを試みることも大 切である。そのためには, 赤血球濃厚液および FFP を 投与しながら, 術前重曹透析を $3 \sim 4$ 時間行い, 術中に 溢水および高カリウム血症を来たし, 感染のコントロー ルを行うに十分な手術を行えない状態に至らないように したい. 我々の症例では, 予定手術に比し緊急手術では, ヘマトクリット值が有意に低く，血清総蛋白量は低下の 傾向を示し, 血清カリウム值は有意に高かった。このこ とが，高い直死率に直結する原因とは思えないが，感染 症を合併し全身状態が不良であることを示唆しており， 術前透析をはじめとする術前管理により直死率が減少す る可能性を示している.

術前管理により, 術後の水分・電解質管理の許容範囲 を広め, 異化え進によるアシドーシスおよび高カリウム 血症を是正し, oncotic pressure を維持するための FFP 投与や15), $\mathrm{O}_{2}$ carrier であるへモグロビンの補充 ${ }^{16)}$ を行 い, 組織および器管の機能維持に努めることが, 創傷治 癒の遷延や縫合不全を防止し, 術後合併症をも減少させ るのではないかと考えている.

術前透析が逆効果になるとすると, ヘパリン投与と体 外循環の影響と思われる。最近は，無あるいは少へパリ ン透析が行われてきており ${ }^{17)}$, 我々は,ヘパリン 300 単位
のプライミングによる EVAL 膜を使用した透析を行っ ており，問題はない，局所へパリン化法でも，プロ夕ミ ン中和によるリバウンドが 4 時間後に来ることを考慮に 入れ， $6 〜 8$ 時間以上たてばへパリンの影響はないもの と考えている。 また，体外循環についても透析患者は体 外循環に慣れの現象があること, 限外滤過による除水に より心負荷が減ること, さらに重曹透析が循環動態に良 い影響を及ぼすこと年等から, 問題はないと考えている.

重症感染症に対する自己防御機構を高めるためには, 術後免疫グロブリンの投与を 3 日間行うとともに, 中心 静脈栄養法による栄養管理および opsonic protein を有 する FFP の連日投与が重要であると考えている ${ }^{19)}$.

重症感染症を初発時には有しないが, 結果的には septic MOF で死亡する 3 ) の疾患群においても, 前述した 術前透析を含む術前管理と術後の自己防御機構の保持に 対する対策は当然行われるべきである。一方，この群に は, 消化管出血症例が含まれており,この対策も重要で ある.透析患者の上部消化管出血に対しては, Cimetidine や Ranitidine hydrochloride 等の $\mathrm{H}_{2}$ 受容体括抗剤及び 水溶性アルミニウム製剤による保存的療法 ${ }^{20)}$ ，エ夕ノー ル局注あるいはレーザー照射等の内視鏡的止血を行って おり，良い成績を得ている ${ }^{21)}$.出血により血清蛋白の著明 な低下と全身状態の悪化を招くことがが多く，このよう な症例には動脈塞栓療法を試みている ${ }^{21}$. 我々は, 消化性 潰瘍術後の吻合部潰瘍出血にて残胃再切除を施行し, 縫合 不全による敗血症にて 1 例失っているので, 消化性潰瘍 の場合 $2 / 3$ 胃切除と迷走神経切断術が必要であると考え ている，このように，保存的療法で止血できない場合あ るいは再出血を繰り返す場合には，手術を行うことにし ているが, 最近 5 年間は消化性潰瘍並びに消化管出血に 対する開腹症例を経験していない。

以上の如き対策を講ずることにより, 緊急手術の直死 率が減少するものと考えるが，さらに検討を要する factor がある。それは慢性透析患者の感染に対する自己防 御機構の問題である. 我々の症例の死因の中でも $68.8 \%$ が septic MOF であり, 敗血症, 肺合併症, 創部感染及 び縫合不全を合併した症例は, 合併症を有する症例の $68.4 \%$ を含めていた。 また, 消化器系術前患者と透析患 者の自己防御機構の検討では, 慢性透析患者では消化器 術前患者に比し細胞性免疫能の低下, 細網内皮系貪食能 の低下および補体系の低下を認めた。 $\mathrm{C}_{3}$ の低下は, 透析 膜による bioactive の関与も考えられ ${ }^{22)}, \mathrm{ACH} 50$ 等の 検討が必要である ${ }^{23)}$. 透析患者では細胞性免疫能が低下 しているとの報告は多いが24 26), 今後透析患者外科感染 症の観点から, neutrophil の各種機能の検索が必要であ ると考える。 


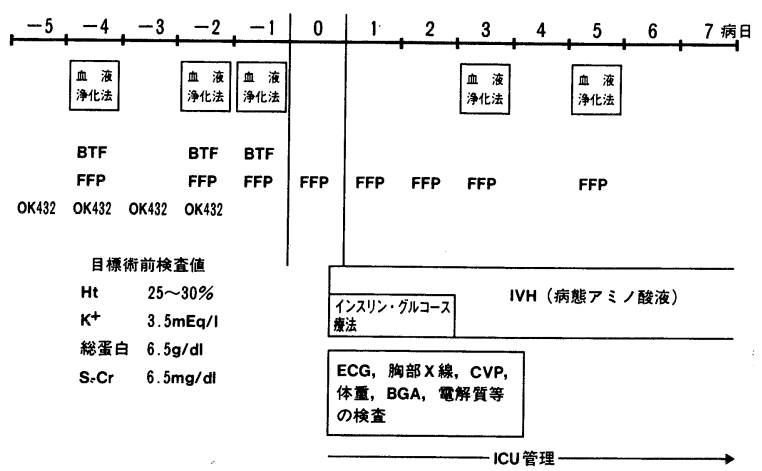

図 3 慢性透析患者に対する特殊 perioperative management

我々は, 低下している透析患者の自己防御機構を賦活 するため, 術前 $\mathrm{OK}-432$ 投与を perioperative manage ment に加えている（図 3 ).ささらに自己防御機構を高め るためには, nutritional support が重要な役割を演じて おり ${ }^{27)}$ ，限られた carrier water 下で $30 \sim 40 \mathrm{kcal} / \mathrm{kg}$ を 投与するには，50\%ブドウ糖をベースとした中心静脈栄 養法が不可欠である ${ }^{3,4)}$. 従来我々は, 腎不全には腎の修 復の促進と BUN の上昇抑制の目的で必須アミノ酸にも ヒスチジンを加えたアミノ酸液を使用していたが28,29), 最近は, 特に胃切除以上の major surgeryには, 術後体 内に低下し，よく取り込まれる分枝鎖アミノ酸の多いア ミノ酸液を用いている ${ }^{30,31)}$. 術後の $\mathrm{kcal} / \mathrm{N}$ についても 1,000 2,000：1 が最適と考えていたが ${ }^{3,4)}$, 毎回の透析 でアミノ酸 5〜6g が透析されることから ${ }^{32)}$, 最近は,

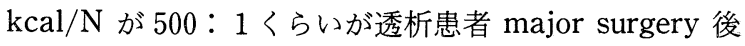
には至適であると考えている。

透析患者では, 免疫能の低下により悪性腫瘍が発生し やすいとされている ${ }^{33)}$. 我々の施設で 1971 年から 1984 年に導入し follow しえた 519 例について検討すると, 20 例 $3.85 \%$ に悪性腫瘍が発生したが，これは吉田ら ${ }^{34)} の$ $3.40 \%$ 一致している.さらに, aged matched general population との比較はしていないが，のべ透析患者数 2,622 人・年を用いて 10 万人対比を行うと， $762 / 10^{5}$ で あり Matas ら ${ }^{35}$ の $1,032 / 10^{5}$ に達しないが, 一般人と比 較して透析患者の悪性腫瘍発生率は，6〜7倍高いもの と推測している ${ }^{36)} .20$ 例のうち消化器系が 11 例, 非消化 器系が 9 例であり, 胃癌 5 例, 子宮癌 3 例, 腎癌 2 例の 他は 1 例ずつであった. 今後, 胃癌をはじめとする消化 器癌併発例が増加するものと思われる。

我々の施設で発生した消化器癌 11 例のうち 9 例は今 回検討した症例であり根治術を施行したが，残りの 2 例 は直腸癌および結腸癌それぞれ 1 例であり，全身状態が
悪く手術を断念し，下血に対してはレーザー照射を行い 一時的には止血しえた。胃癌手術施行例の第 1 , 第 2 例 は進行癌であったが, 最近の 3 例は早期癌のうちに発見 されている. 悪性腫瘍早期発見のために, 透析患者が消 化器症状を訴えた場合, 積極的に上部消化管造影および 超音波画像診断等を行っており，手術可能な肝細胞癌も 診断した. 胆囊結腸重複癌は, 結腸ポリープ癌が自然脱 落し, 粪中より標本を採取して診断がついた症例であり， 胆囊癌は術中に判明した．持続性の腹痛あるいは下血の 訴えのあったときは, 腹部単純 X線確認の上, めんどう がらずに注腸造影を行う必要性を痛感した。また患者の 愁訴を聞きだすことにより，へパリンにより助長される と思われる消化器癌からの出血が, 一般人より早期に発 見される可能性もあると考えている。

我々の術前検查値の目標は, ヘマトクリット值 $25 \sim 30 \%$, 血清カリウム值 $3.5 \mathrm{mEq} / l$, 血清総蛋白量 6.5 $\mathrm{g} / \mathrm{d} l$, 血清クレアチニン濃度 $6.5 \mathrm{mg} / \mathrm{d} l$ であり, preoperative management により容易に達成されており, 今後 もこの值で良いと考えている4).

開腹時の術中輸液は，一般患者の $10 \mathrm{~m} l / \mathrm{kg} / \mathrm{h}$ に対し $5 \sim 6 \mathrm{ml} / \mathrm{kg} / \mathrm{h}$ で十分であり, 種類は開始輸液 ( I 号輸液) を使用している．出血に対しては，赤血球輸血は控え目 にし，FFP中心に行っており，この方が，循環系の負荷 を軽減し，oncotic pressure の保持にも良いと考えてい る. GI 療法を駆使した中心静脈栄養法により高カリウム 血症及び溢水を予防し，第 3 病日に EVAL 膜ダイアラ イザーを用い少へパリン透析を行っており, 術後初回透 析による出血は認められなかった。

透析患者の悪性腫瘍に対する抗腫瘍剤の投与について は定説がなく, 副作用が強いと報告されており ${ }^{37 ~ 39), ~}$ 我々は投与していない.しかし, stage IIIの進行癌には, 一般患者に抢いて biological response modifier と tegafur の同時投与により効果があるとの報告 ${ }^{40)}$ があ り, 我々も stage IIIの症例には胃癌免疫化学療法を行う 必要があると考えている。 その際, tegafur の投与量は, 一般患者の $1 / 3 \sim 1 / 2$ である $200 \sim 300 \mathrm{mg} / \mathrm{day}$ が至適で あろうと考えている．また，根治性をどう追求するかと いう問題点については, curative な手術を行うべきであ り, 例えば胃癌では, リンパ節郭清後の浸出液の問題も あるが，少なくともII群までの所属リンパ節の郭清を 行っており, 電気メスで漿膜を切開し, 出血点は丹念に 結禁している.

透析患者悪性腫瘍併発例については，慢性腎不全の予 後についても考慮する必要があり ${ }^{41)}$, 特に糖尿病性腎症 等の系統的疾患についてその必要がある ${ }^{42)}$. 今後, 抗腫瘍 剤の投与方法および手術による根治性の追求の問題につ 


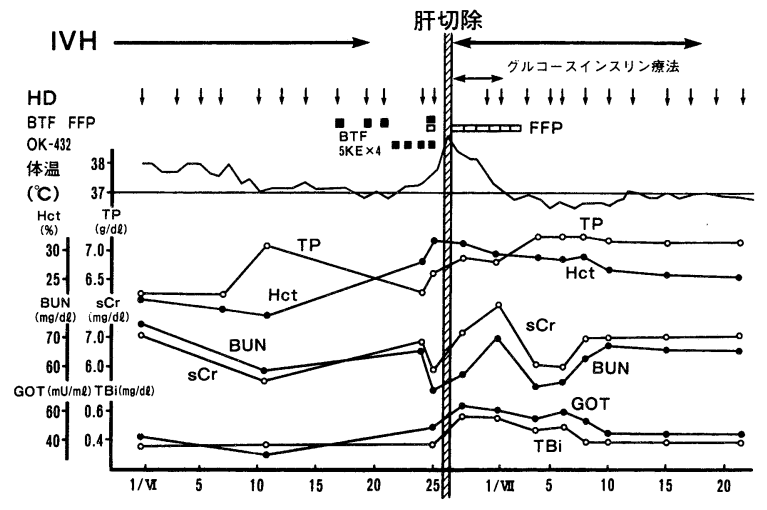

図 4 症例 51 歳男性（糖尿病性腎症）肝細胞癌に て肝外側区域切除施行

いて検討する必要があると思われる.

症例を供覧する。症例は 51 歳男性で 1973 年糖尿病発 症し, 1984 年 3 月に糖尿病性腎症にて血液透析を開始し た. 1985 年 4 月 10 日腹部膨満感を訴え腹部超音波診断 施行し, 肝左葉の腫瘤が認められた. dynamic CT およ び MR-CT にて肝外側区域に $5 \times 6 \mathrm{~cm}$ の肝細胞癌を認 めると診断された。肝動脈塞栓療法施行後胃ビラン強度 となり摄食不良のため中心静脈栄養法を施行し, 術前管 理を行った（図 4 ）。6 月 26 日全麻下にて肝外側区域切 除を行い, 術後 GI 療法を行い, 術後第 3 病日初回透析 を施行した. 術後経過良好にて術後 46 病日退院した.

肝癌の手術適応を考える場合, 我々の症例は外側区域 切除を安全に施行したが, lobectomy を行う症例には多 少の riskを伴うものと考える. しかし, 基本的には，十 分な perioperative management を施行し, 透析を熟知 した外科医が手術を行えば，透析患者ということのため に手術適応がなくなることはないものと考えている.

\section{まとめ}

1 ) 千葉大学第 2 外科抒よび千葉社会保険病院にて, 1966 年 12 月から 1985 年 6 月までに 1355 例の透析患者 外科手術を経験した。このうち併存病変に対する手術, 137 例についてさまざまな検討を行い, 透析患者の外科 手術に対する問題点と対策について若干の考察を加えて 報告した。

2) 予定手術 74 例に直死例はないが, 緊急手術 63 例 中 16 例が直死例であり, 直死率は, 緊急手術群において 有意に高かった。緊急手術群では術前管理が不十分であ り, 重症感染症を有する症例が多く, 合併症併発例では septic multiple organ failure で死亡する症例が多かっ た.

3 ）慢性透析患者の感染に対する自己防御機構を検討 すると, 消化器術前患者に比して, 細胞性免疫能の低下,
細網内皮系貪食能の低下および補体系の低下を認めた。 つまり慢性透析患者は, immunocompromised host であ ることが判明した。

4 ) 緊急手術においては, 術前の時間的余裕を検討し, EVAL 膜を用いた少へパリン術前重曹透析を含めた術 前管理を行い, 手術による感染症のコントロールを可能 な限り行い, 術後には $\gamma$-グロブリン製剤や opsonic protein を含む FFP を投与し, 自己防御機構の賦活に努め る必要がある。

5 ) 予定手術に対しては, 血液浄化法, GI 療法等を組 み合わせた perioperative management および biological response modifier である OK-432 の術前投与によ る免疫賦活療法を施行し, 術後合併症の予防に努めた。

6 ) 我々の施設で 1971 年から 1984 年に導入し follow しえた 519 例中 20 例 $3.85 \%$ に悪性腫瘍の発生を認め た。このうち 11 例が消化器癌であった。患者の愁訴に注 目し, 早期胃癌 3 例㧍よび手術可能な肝細胞癌 1 例を診 断したが,これらを含む消化器癌 10 例に根治術を施行し 致命的な合併症はなかった。透析患者の平均年齢が癌年 齢に達しつつあり, 悪性腫瘍の早期発見に努める必要が ある。

7 ）一般患者に手術適応のある疾患で，透析患者であ るために手術適応がなくなるという疾患はなくなりつつ あると考える. しかし，抗腫瘍剤の投与方法抢よび手術 による根治性の追求については，糖尿病性腎症等の系統 的疾患の増加とその予後が不良なことから, 慢性腎不全 そのものの予後について考慮する必要があり, 今後の問 題点であると考える.

\section{文献}

1）小高通夫：わが国の慢性透析療法の現況. 1984 年 12 月 31 日現在。透析会誌，19(1)：1-21，1986.

2）飯島一彦，片山正夫，稲葉英夫，日下部伸子，安東 昌夫, 三枝陸朗，米澤利英：透析患者の外科手術と 麻醉管理。透析会誌, $13: 115-120,1980$.

3）小高通夫, 添田耕司 : 手術のコツ一輸血. 輸液のコ ツ一。外科治療, $52: 329-336,1985$.

4）大川昌権, 小高通夫, 平沢博之, 小林弘忠, 添田耕 司, 林 春幸, 管井桂雄, 佐藤 博, 嶋田俊恒, 入 江康文：透析と外科手術一perioperative management を中心に一. 透析会誌, $13: 95-100,1980$.

5）平澤博之, 小高通夫, 嶋田俊恒, 原 荘, 野村庸一, 三井 静, 沼野 健, 相馬光弘, 渡辺義二, 小林弘 文, 佐藤 博: 腎不全と手術一手術患者の管理を中 心として一. 臨床外科, $29: 101-106,1974$.

6）寺岡 慧，太田和夫，高橋公太，東間 紘，阿岸鉄 
三，吉田喜美子：透析患者と外科手術．日本臨床， 43 ：特別号，612-622，1985.

7) Brenowitz, J. B., Williams, C. D., Edwards, W. S. : Major surgery in patients with chronic renal failure. Amer. J. Surg., 134 : 765-760, 1977.

8) Silberman, H. : Renal failure and the surgeon. S. G. O., $144:$ 775-784, 1977.

9）小林 進, 平澤博之, 小高通夫, 佐藤 博: 障害肝 ラットの腹膜炎後生存率に及ぼす immunopotentiator の効果. 医学のあゆみ, 130： 807-808, 1984.

10）平澤博之, 菅井桂雄, 林 春幸, 添田耕司, 小林弘 忠, 大竹喜雄, 田畑陽一郎, 小高通夫, 佐藤 博 : 術後感染症に対する自己防御機構の検討一II. 細綱 内皮系機能の検討とその抑制に対する対策一.外科, $43: 47-52,1981$.

11）菅井桂雄, 平澤博之, 小林弘忠, 添田耕司, 林 春 幸, 大竹喜雄, 小高通夫, 佐藤 博: 術後感染症に 対する自己防御機構の検討 (I) -skin test の有用 性および anergy の治療について一. 外科, 42 ： 1560-1564, 1980.

12）大平整爾, 阿部憲司, 佐々木偉夫, 田口宏一, 佐野 秀一, 久木田和丘：慢性透析患者にみられた虚血性 腸管壊死の 3 例，腎と透析，16:605-610，1984.

13）平澤博之, 小高通夫, 添田耕司, 佐藤 博: Hemoperfusion. 外科診療, $22: 1098-1104,1980$.

14) Twardowski, Z. T., Alpert, M. A., Gupta, R. C., Nolph, K. D., Madsen, B. T. : Circulating immune complexes; possible toxins responsible for serositis (pericarditis, pleuritis, and peritonitis) in renal failure. Nephron, 35 : 190-195, 1983.

15) Demling, R. H., Manohar, M., Will, J. A.; Belzer, F. O, : The effect of plasma oncotic pressure on the pulmonary microcirculation after hemorrhagic shock. Surgery, $86: 323-328,1979$.

16) Heughan, C., Chir, B., Grislis, G., Hunt, T. K. : The effect of anemia on wound healing. Ann. Surg., 179 : 163-167, 1974.

17）松井則明：透析に打ける新しい抗疑固薬. 腎と透析, $16: 285-290.1984$.

18) Hampl, H., Schafer, G. E., Kessel, M. : Haemodynamic state in severe chronic renal failure, pathophysiological aspects of cardiovascular function and the importance of bicarbonate dialysis. Nephron, 39 : 102-111, 1985.

19）平澤博之, 菅井桂雄, 小林弘忠, 林 春幸, 大竹喜
雄, 織田成人, 小林 進, 小高通夫, 佐藤 博 : 外 科領域における感染に対する自己防御機構の検討と 免疫不全に対する対策. 外科, $44 ： 1125-1132,1982$.

20) Priebe, H. J., Skillman, J. J., Bushnell, L. S., Long, P. C., Silen, W. : Antacid versus cimetidine in preventing acute gastrointestinal bleeding. N. Eng. J. Med., 302 : 426-430, 1980.

21）小林 進, 平澤博之, 小林弘忠, 田畑陽一郎, 大川 昌権，添田耕司，織田成人，室谷典義，竜 崇正， 神津照雄, 小高通夫, 佐藤 博: 腎不全における上 部消化管出血に対する総合的治療. 腹部救急診療の 進歩， 3 : 497-501， 1984.

22）鈴木好夫，内田順子，岡崎祐子，三浦雅弘，原 茂 子, 葛原敬八郎, 二瓶 宏, 三村信英 : 透析膜生体 適合性の研究（I ）－ダイアライザー充填液抢よび 洗條液による補体活性化一. 腎と透析, $16: 551-555$, 1984.

23）渡邊干之, 石山 腎, 斎藤英昭, 市倉 隆, 黒岩厚 二郎, 井上 暁, 森岡恭彦: 補体, オプソニン活性 の検査と評価, 救急医学, $9: 801-809,1985$.

24) Baum, J., Cestero, R. V. M., Freeman, R. B. : Chemotaxis of the polymorphonuclear leukocyte and delayed hypersensivity in uremia, Kidney Int., 7 : s 147-s 153, 1975.

25) Perese censchi, G., Blum, M., Aviram, A., Spirer, Z. H. : Impaired neutrophil response to acute bacterial infection in dialyzed patients. Arch. Intern. Med., 141 : 1301-1302, 1981.

26) Cappel, R., Liesnard, V. C., Dratwa, M. : Impaired humoral and cell-mediated immune responses in dialyzed patients after influenza vaccination. Nephron, 33 : 21-25, 1983.

27) Glassock, R. J. : Nutrition, immunology, and renal disease. Kidney Int., 24 (Suppl) : s 194-s 198, 1983.

28）相馬光弘, 小高通夫, 野村庸一, 小林弘忠, 田畑陽 一郎, 大川昌権, 添田耕司, 平澤博之, 佐藤 博 : 急性腎不全に対する必須アミノ酸液 (AMI-U-II) の使用経験，現代の診療，20：1621-1623，1978.

29) Abel, R. M., Beck, C. H., Abbott, W. M., Ryan, J. A., Barnett, G. O., Fischer, J. E. : Improved survival from acute renal failure after treatment with intravenous essential L-amino acids and glucose. N. Eng. J. Med., 288 : 695-699, 1973.

30) Cerra, F. B., Upson, O., Angelico, R., Wiles, C., Lyons, J. Faulken bach, L., Paysinger, J. : Bran- 
ched-chains support postoperative protein synthesis. Surgery, $92: 192-198,1982$.

31) Tizianello, A., Deferrarc, G., Garidbotto, G., Robando, C., Lutman, M.,Passerone, G., Bruzzone, M. : Branched-chain amino acid metabolism in chronic renal failure, Kidney Int., 24 (Supple) : s 17-s 22, 1983.

32）岡村克章, 中浜 肇, 山内 淳, 白井大禄: CAPD に おける蛋白質・アミノ酸代謝および脂質代謝の研究, 腎と透析, $14: 167-173,1983$.

33) Jacob, c., Brunner, F. P., Brynger, H., Chantler, C., Donckerwolcke, R. A., Hathway, R. A., Kramer, P., Selwood, N. H., Wing, A. I. : Malignant diseases in Patients treated by dialysis and transplan -tation in Europe. Transplantation Proc., 13 : 729 $-732,1981$.

34）吉田栄一, 堀見忠司, 二宮基樹, 岡林孝弘, 平松 聡, 長江聡一, 金田道弘, 向井晃太, 武田 功, 析田薰 三：慢性腎不全患者の免疫能一発癌性に関する臨床 的および基礎的研究一. 第 30 回人工透析研究会総 会, 東京, 1985 .

35） Matas, A. J., Simmons, R. L., Kjellstrand, C. M., Buselmeier, T. J. : Increased incidenece of malignancy during chronic renal failure. Lancet $1: 883$
$-885,1975$.

36) Jacobs, C., Reach, I., Degoulet, P. : cancer in patients on hemodialysis. N. Eng. J. Med., 300 : 1279-1280, 1979.

37) Petrilli, E. S., CastaLdo, T. W., Matutat, R. J., Ballon, S. C., Gutierrez., M. L. : Bleomycin pharmacology in relation to adverse effects and renal function in cervical cancer patients. Gynecol. Oncol., $14: 350-354,1982$.

38）阿部富弥, 楠見博明, 西野美穂, 岡 文俊, 湯川 進 : 人工透析による癌治療の研究. 透析会誌, 12 : 1017-1018， 1979.

39）新保隆郎, 仲山実, 中村一賀, 斎藤 博, 佐藤 威： 血液透析患者におけるマイトマイシン $\mathrm{C}$ 静注後血中 濃度の推移一胃癌合併例に対する使用経験一。透析 会誌, $12 ： 1019-1020,1979$.

40）三輪恕昭：胃癌の補助免疫化学療法. 日消外会誌, $18: 1951-1960,1985$.

41）小高通夫，添田耕司，田栗正章：血液浄化療法の適 応患者の推移と将来予測. 臨床医, $11: 104-106$, 1985.

42）小高通夫, 添田耕司, 嶋田俊恒：糖尿病性腎症の現 況. 臨床透析, 1:531-539, 1985. 